УДК 342.98:35.082(477)

DOI https://doi.org/10.32837/pyuv.v1i3(28).319

Н. С. Панова

кандидат юридичних наук, доцент кафедри конституиійного, адміністративного і міжнародного права Київського інституту інтелектуальної власності і права Національного університету «Одеська юридична академія»

\title{
ВИМОГИ ДО ОСІБ, ЯКІ ПРЕТЕНДУЮТЬ НА ВСТУП НА ДЕРЖАВНУ СЛУЖБУ
}

Актуальність теми. Становлення демократичної, правової, соціальної держави, інтеграція України в Європейське співтовариство, здійснення адміністративної реформи і реформи системи державної служби передбачають підготовку державних службовців, які здатні неухильно відстоювати права і свободи людини і громадянина і які володіють професійними уміннями і навичками, що ґрунтуються на сучасних спеціальних знаннях, аналітичних здібностях та майстерності застосування засобів і методів управлінської науки, стратегічному мисленні та особистісними якостями, необхідними для прийняття та успішної реалізації управлінських рішень. Питання відбору професійних та кваліфікованих осіб на посади державної служби було і залишається до теперішнього часу надзвичайно важливим та актуальним, особливо з огляду на докорінні зміни, які відбуваються у всіх сферах суспільного життя і насамперед у державному апараті.

Стан наукового дослідження питання. Не дивлячись на те, що це питання є надзвичайно важливим та актуальним, у теорії адміністративного права йому не приділялося належної уваги. Більше того, цілком справедливо буде зазначено, що це питання практично не досліджувалося, особливо у контексті тих змін, які протягом останніх років стосувалися інституту державної служби. Йдеться передусім про науково-теоретичні напрацювання із обраної проблеми.

Виклад основного матеріалу. Відповідно до ч. 1 ст. 20 Закону «Про державну службу» [1] (далі - чинний Закон) вимогами до осіб, які претендують на вступ на державну службу, є винятково вимоги щодо їхньої професійної компетентності. При цьому слід звернути увагу на те, що поняття «професійна компетентність» $€$ новим для чинного Закону «Про державну службу» i попереднім Законом [2] воно не передбачалося. Професійна колпетентність - це здатність особи у межах визначених за посадою повноважень застосовувати спеціальні знання, уміння (здатність належно виконувати певні дії, заснована на доцільному використанні особою набутих знань і навичок) та навички (тобто дії, складові частини яких у процесі формування стають автоматични- ми), виявляти відповідні моральні та ділові якості для належного виконання встановлених завдань i обов'язків, навчання, професійного та особистісного розвитку.

Аналіз встановлених чинним Законом вимог дає підстави зазначити, що ці вимоги слід поділити на загальні, які визначені чинним Законом, та спеціальні, які пред'являються: а) до осіб, які претендують на зайняття посад державної служби категорій «Б» i «В», суб’єктом призначення з урахуванням рекомендацій, затверджених НАДС; б) до осіб, які претендують на зайняття посад державної служби категорії "А», типовими вимогами, затвердженими Кабінетом Міністрів України.

Загальними вимогами для посад категорії «А» є такі.

1. Загальний стаж не менше 7 років. Важливо зазначити, що загальний стаж - це сумарна тривалість роботи робітником або службовцем, або в іншій суспільно-корисній діяльності, якщо ï включення в трудовий стаж передбачено чинним законодавством. Натепер у чинному законодавстві використовується поняття «страховий стаж» - період (строк), протягом якого особа підлягає загальнообов'язковому державному пенсійному страхуванню та за який щомісяця сплачено страхові внески в сумі, не меншій, ніж мінімальний страховий внесок. Будь-який період роботи, який відповідно до закону зараховується до страхового стажу, включається у загальний стаж [3]. Загальний стаж слід відрізняти від спеціального стажу, тобто тривалості роботи у певних сферах, або на певних посадах (напр.: у сфері державної служби; на керівних посадах тощо).

2. Досвід роботи. На відміну від загального стажу роботи, який $\epsilon$ неконкретизованим, вимоги щодо досвіду роботи є більш чіткими: а) на посадах державної служби категорій «А» чи «Б» (див. ст. 6 чинного Закону); б) на посадах не нижче керівників структурних підрозділів в органах місцевого самоврядування; в) на керівних посадах у відповідній сфері (мається на увазі сфера державної служби, сфера служби в органах місцевого самоврядування) не менш як 3 роки. При цьому слід зазначити, що необхідним є один із трьох названих досвідів роботи. Щодо поняття «керівна поса- 
да» важливо акцентувати увагу на тому, що чинне законодавство не надає визначення цього поняття та не розкриває його змісту. Виходячи з поняття та сутності таких термінів, як «безпосередній керівник» i «посада державної служби», можна зробити висновок, що керівні посади (у контексті цього положення) - це посади публічної служби, які заміщують публічні службовці і до посадових обов'язків яких належить виконання виконавчо-розпорядчих повноважень;

3. Вільне володіння державною мовою. Цей критерій також є новітнім порівняно із попереднім Законом, який такої вимоги не передбачав. Обов' язок володіння державними службовцями державною мовою передбачено у п. 3 ч. 1 ст. 9 Закону «Про забезпечення функціонування української мови як державної» [4]. Відповідно до ст. 10 Конституції України державною мовою в Україні є українська мова (див. П. 1.2 коментарю до ст. 2 цього Закону).

Первинно у ст. 20 чинного Закону було передбачено, що рівень володіння державною мовою визначався під час атестації осіб, які претендують на вступ до державної служби [5]. Здійснення атестації покладалося на вищий навчальний заклад, який відповідно до ліцензії здійснює підготовку здобувачів вищої освіти у галузі знань «Публічне управління та адміністрування». На теперішній час Законом «Про внесення змін до деяких законів України щодо перезавантаження влади» [6] внесено зміни до чинного Закону, у тому числі і до п. 5 ч. 1 ст. 25 Закону. Зазначеними змінами передбачено, що переможець конкурсу, оголошеного після 25.09.2019 р., має надати копії документів про підтвердження рівня вільного володіння державною мовою. Такими документами, на думку НАДС, можуть бути, зокрема: або а) документ державного зразка про середню / вищу освіту, в якому зазначено про вивчення предмету / дисципліни, що підтверджують знання української мови; або б) посвідчення щодо вільного володіння державною мовою, отримані до 25.10.2019 р. Слід звернути увагу на те, що зазначений перелік документів не є вичерпним [7].

Аналіз зарубіжного законодавства свідчить, що володіння державною мовою - це вимога, яка зумовлена характером діяльності публічних службовців, що полягає у знанні державної мови та її активному використанні під час виконання покладених завдань і функцій. Вимога володіння державною мовою зазвичай прямо встановлюється в державах, де є чималі іншомовні національні групи, наприклад, в Естонії [8], Литві [9], Латвії [10]. У мононаціональних країнах (Польща, Болгарія) в законах про публічну (державну) службу цю умову не передбачено $[11 ; 12]$.

4. Володіння інозелною ловою, яка є однією з офіиійних мов Ради Європи: англійська та французька мови [13]. Ця вимога відповідно до абз. 1 п. 1 Прикінцевих та перехідних положень чинного Закону набрала чинності з 01.05.2018 p. Натепер час порядок атестації осіб, які претендують на зайняття посад державної служби категорії «A», і завдання затверджує Комісія з питань вищого корпусу державної служби (далі - Комісія). Так, 12.06.2018 р. на засіданні Комісії затверджено відповідні тестові завдання [14], які мають відповідати критеріям рівня володіння мовою В1 за системою володіння іноземними мовами, що використовуються в ЄC (CEFR). Тестові завдання включають у себе лексико-граматичний тест, перевірку розуміння письмового тексту, умінь і навичок сприйняття усного мовлення (аудіювання), умінь і навичок висловлювати свою думку іноземною мовою. Усі тестові завдання, окрім тих, що обрані кандидатами для проходження щодо перевірки володіння іноземною мовою кандидатів на зайняття вакантних посад державної служби категорії «A», $€$ конфіденційними. Рекомендований час написання тестування має становити 2 години 3 моменту отримання кандидатами відповідного тестування, з яких 15 хвилин має бути виділено для аудіювання. Тестування оцінюється за 100-бальною шкалою, з яких прохідними $є$ 75 балів і вище. Оцінювання тестування здійснюють залучені експерти. Критерії для проведення оцінювання володіння іноземною мовою затверджено рішенням Комісії (прот. № 10 засідання Комісії від 12.06.2018 р.) [15].

Загальні вимоги для посад категорії «Б» поділяються на два види залежно від юрисдикції державного органу.

У разі, якщо юрисдикція такого органу або його апарату поширюється на всю територію України, встановлено такі вимоги: досвід роботи на посадах державної служби категорій «Б» чи «В» або досвід служби в органах місцевого самоврядування, або досвід роботи на керівних посадах підприємств, установ та організацій незалежно від форми власності не менше 2 років, вільне володіння державною мовою. Насамперед заслуговує на увагу положення щодо державного органу, юрисдикція якого поширюється на всю Україну, тобто йдеться про такі органи, як: Апарат ВРУ; Координаційний центр забезпечення взаємодії з КМУ; Урядовий офіс координації європейської та євроатлантичної інтеграції, Секретаріату КМУ, Офіс Президента України; допоміжні, консультативно-дорадчі органи, утворені Президентом України тощо. Окремо слід звернути увагу, що йдеться також про апарати (секретаріати) державних органів, тобто робочі органи, що забезпечують функціонування самих державних органів. Саме на ці органи, відповідно до їх установчих нормативних актів, і покладається завдання забезпечення організації і функціонування відповідних органів. Важливим $€$ те, що служба в апаратах зазвичай надає особі ста- 
тусу державного службовця (окрім працівників), що виконують функції з обслуговування. Такими органами є: Апарат ВРУ [16; 17], Офіс Президента України [18; 19], Секретаріат КМУ [20; 21], Апарат РНБО [22; 23], Секретаріат КСУ [24], апарати ВСУ, вищих спеціалізованих судів, судів [25], Секретаріат ЦВК [27], Секретаріат Уповноваженого ВРУ з прав людини [28; 29], Апарат Рахункової палати [30] тощо. Щодо досвіду служби в органах місцевого самоврядування слід зазначити, що це професійна діяльність на постійній основі осіб, які займають: а) виборні посади, на які вони обираються на місцевих виборах; б) виборні посади, на які вони обираються або затверджуються відповідною радою; в) посади, на які вони призначаються сільським, селищним, міським головою, головою районної, районної у місті, обласної ради на конкурсній основі чи за іншою процедурою, передбаченою законодавством України.

У разі, якщо юрисдикція державного органу поширюється на територію однієї або кількох областей, міста Києва або Севастополя, та його апараті - досвід роботи на посадах державної служби категорій «Б» чи «В» або досвід служби в органах місцевого самоврядування, або досвід роботи на керівних посадах підприємств, установ та організацій незалежно від форми власності не менше двох років, вільне володіння державною мовою.

Для посад категорії «Б» в іншому державному органі, окрім тих, що зазначені вище - досвід роботи на посадах державної служби категорій «Б» чи «В» або досвід служби в органах місцевого самоврядування, або досвід роботи на керівних посадах підприємств, установ та організацій незалежно від форми власності не менше 1 року, вільне володіння державною мовою. При цьому слід зазначити, що документом для визначення відповідного досвіду роботи може бути як трудова книжка, так і інші документи, зокрема: довідки, виписки з наказів, дані, наявні в реєстрі застрахованих осіб Державного реєстру загальнообов'язкового державного соціального страхування, а також копії контрактів, копії установчих документів та інші дані, які можуть бути підтвердженими документально.

Загальними вимогами для посад категорії «В» $€$ : наявність вищої освіти ступеня молодшого бакалавра або бакалавра за рішенням суб'єкта призначення, вільне володіння державною мовою. При цьому слід звернути увагу на те, що в первинній редакції цього положення словосполучення «за рішенням суб’єкта призначення» щодо ступеня бакалавра або молодшого бакалавра не було. Таким чином, законодавець поклав вирішення цього питання на розсуд суб'єкта призначення. Слід зазначити, що: а) ступінь бакалавра (освітній ступінь, що здобувається на першому рівні вищої освіти) присуджується закладом вищої освіти у результаті успішного виконання здобувачем вищої освіти освітньо-професійної програми, обсяг якої становить 180-240 кредитів СКТС. Обсяг освітньо-професійної програми для здобуття ступеня бакалавра на основі ступеня молодшого бакалавра або молодшого спеціаліста визначається закладом вищої освіти; б) молодшого бакалавра (освітньо-професійний ступінь, що здобувається на початковому рівні (короткому циклі) вищої освіти) присуджується закладом вищої освіти у результаті успішного виконання здобувачем вищої освіти освітньо-професійної програми, обсяг якої становить 120-150 кредитів СКТС. Обсяг освітньо-професійної програми для здобуття ступеня молодшого бакалавра на основі ступеня молодшого спеціаліста визначається закладом освіти).

Спеціальні вимоги до осіб, які претендують на зайняття посад державної служби категорій «Б» $\mathrm{i}$ «В», визначаються суб’єктом призначення з урахуванням рекомендацій, затверджених НАДС. Спеціальні вимоги визначає суб'єкт призначення шляхом затвердження умов проведення конкурсу за формами, визначеними Порядком проведення конкурсу на зайняття посад державної служби, а розробляє їх служба управління персоналом державного органу. За змістом спеціальні вимоги є описом вимог до досвіду роботи осіб, які претендують на зайняття посад державної служби категорій «Б» $\mathrm{i}$ «В», їх освіти, компетентностей, професійних знань, необхідних для ефективного виконання обов'язків за відповідною посадою державної служби. При цьому вимоги щодо освіти та досвіду роботи можуть мати уточнюючий характер щодо галузей знань та/або спеціальностей, за якими здобуто вищу освіту, досвіду роботи у конкретній сфері. Слід зазначити, що спеціальні вимоги визначаються з урахуванням вимог спеціальних законів, що регулюють діяльність відповідного державного органу, положення про державний орган, завдань та змісту роботи, яку зобов'язаний виконувати державний службовець відповідно до положення про структурний підрозділ та посадової інструкції. Ці вимоги описуються з рівнем деталізації, достатнім для відбору осіб, які претендують на зайняття посад державної служби, з одночасним встановленням компонентів кожної такої вимоги.

Особи, які претендують на зайняття посад державної служби категорії «А», мають відповідати i спеціальним вимогам, передбаченим Типовими вимогами до осіб, які претендують на зайняття посад державної служби категорії «А» [31]. Спеціальні вимоги становлять насамперед вимоги щодо компетентностей: а) управління змінами: вміння формувати план змін, управляти змінами та реакцією на них, оцінювати ефективність змін; б) прийняття ефективних рішень: здатність своєчасно приймати виважені рішення; вміння аналізувати 
альтернативи; спроможність на виважений ризик; автономність та ініціативність щодо прийняття пропозицій/рішень; в) лідерство: вміння мотивувати до ефективної професійної діяльності; сприяння всебічному розвиткові особистості; вміння делегувати повноваження та управляти результатами діяльності; здатність до формування ефективної організаційної культури державної служби; г) комунікація та взаємодія: вміння визначати зацікавлені і впливові сторони та розбудовувати партнерські відносини; здатність ефективно взаємодіяти - дослухатися, сприймати та викладати думку; вміння публічно виступати перед аудиторією; здатність переконувати інших за допомогою аргументів та послідовної комунікації; д) досягнення результатів: здатність до чіткого бачення результату діяльності; вміння фокусувати зусилля для досягнення результату діяльності; вміння запобігати та ефективно долати перешкоди; ж) стресостійкість: вміння управляти своїми емоціями; здатність до самоконтролю та до конструктивного ставлення до зворотного зв'язку, зокрема критики; з) управління ефективністю та розвиток людських ресурсів: вміння управляти як людськими ресурсами, так і проектами; вміння організовувати роботу і контролювати їі виконання; здатність до мотивування тощо. Слід зазначити, що наведений перелік компетентностей не є вичерпним.

Цікавим є зарубіжний досвід щодо вимог до осіб, які претендують на посади публічної служби, зокрема, стосовно освіти. Наявність відповідної освіти є однією з визначальних умов для вступу на публічну службу практично в усіх країнах Свропейського Союзу. При цьому градація відповідної освіти залежно від країни, конкретної посади, виду служби має велике значення: для зайняття одних посад достатньо середньої освіти, для інших - необхідною є вища освіта із ступенем бакалавра або магістра.

Найбільш жорсткою є система вимог щодо освіти у Німеччині. Відповідно до Федерального закону Німеччини «Про статус чиновників» [32] для: а) службової кар'єри служби підвищеної категорії вимагається: шкільне навчання, яке надає право навчатися у вищому закладі, і проходження підготовчої служби у три роки; б) службової кар'єри служби вищої категорії вимагається: трирічна, закінчена іспитом освіта у вищому навчальному закладі іпроходження підготовчоїслужби у два роки.

Досить чітка взаємозалежність між рівнем освіти і службовим званням державного службовця передбачена $§ 7$ Закону Чехії «Про службу державних службовців ...», відповідно до якого державному службовцеві, службова посада якого вимагає: а) середньої професійної освіти - присвоюється службове звання "референт»; б) повної середньої шкільної освіти - «професійний рефе- рент»; в) повної середньої шкільної освіти - «референт-спеціаліст»; г) повної середньої шкільної освіти - «вищий референт»; д) повної середньої шкільної освіти - «вищий референт-спеціаліст»; якщо державний службовець займається контрольною діяльністю - йому присвоюється службове звання «інспектор»; ж) вищої професійної освіти або університетської освіти з дипломом бакалавра - «старший референт» або «старший інспектор»; з) університетської освіти з дипломом бакалавра - «радник»; к) університетської освіти 3 дипломом магістра - «професійний радник», «старший радник», «міністерський радник», «вищий міністерський радник», «старший міністерський радник» [33].

Висновки. Таким чином, враховуючи важливість вимог до осіб, які претендують на зайняття посад державної служби у контексті подальшого удосконалення інституту державної служби та його адаптації до стандартів ЄС, слід зазначити, що як належне правове регулювання цих вимог, так і їх відповідне науково-методологічне забезпечення дають можливість доступу до державної служби кваліфікованим, професійним та авторитетним особам. Як видається, одним із важливих напрямів подальшого удосконалення системи вимог є вимоги щодо особистісних якостей кандидатів на посади державної служби.

\section{Iimepamypa:}

1. Про державну службу : Закон України від 10.12.2015 p. Дата оновлення: 01.01.2020 p. URL: https://zakon.rada.gov.ua/laws/show/889-19.

2. Про державну службу : Закон України від 16.12.1993 p. URL: (втратив чинність).

3. Про загальнообов' язкове державне пенсійне страхування: Закон України від 09.07.2003 р. Дата оновлення: 01.01.2019 p. URL: https://zakon.rada.gov.ua/ laws/show/1058-15.

4. Про забезпечення функціонування української мови як державної: Закон України від 25.04.2019 р. URL: https://zakon.rada.gov.ua/laws/show/2704-19.

5. Про організацію проведення атестації осіб, які претендують на вступ на державну службу, щодо вільного володіння державною мовою: Постанова КМУ від 26.04.2017 р. Дата оновлення: 04.11.2017 р. URL: https://zakon.rada.gov.ua/laws/show/301-2017$\% \mathrm{D} 0 \% \mathrm{BF}$ (втратила чинність).

6. Про внесення змін до деяких законів України щодо перезавантаження влади: Закон України від 19.09.2019 р. Дата оновлення: 01.02.2020 p. URL: https://zakon.rada.gov.ua/laws/show/117-20.

7. Щодо підтвердження рівня вільного володіння державною мовою переможцем конкурсу на зайняття посади державної служби: роз'яснення НАДС від 17.01.2020 p. URL: file://C:/Users/pc/Desktop/\% D0\% 9A $\%$ D0 $\%$ 9E $\%$ D0 $\%$ 9C $\%$ D0 $\%$ 95 $\%$ D0 $\%$ 9D $\%$ D0 $\%$ A2 $\%$ D0 $\%$ 90\% D0 $\%$ A0 $\%$ D1 $\% 80 \%$ D0 $\%$ B5 $\%$ D0 $\%$ B $4 \%$ D0 $\%$ B0\% D0 \% BA $\%$ D $1 \% 86 \%$ D $1 \% 96 \%$ D1 $\% 8 F-2020 /$ $\%$ D0 $\%$ 9D $\%$ D0 $\%$ 9F $\%$ D0 $\% 90 \% 20 \%$ D0 $\% 9 D \%$ D0 $\%$ $90 \%$ D0 $\%$ 94\% D0 $\%$ A1 $\%$ D0 $\%$ B2 $\%$ D0 $\%$ BE $\%$ D0 $\%$ BB $\%$ D0 $\%$ BE $\%$ D0 $\%$ B $4 . \%$ D0 $\%$ B $\%$ D0 $\%$ B5 $\%$ D1 $\% 80 \%$ D0 $\%$ B6. $\%$ D0 $\%$ BC $\%$ D0 $\%$ BE $\%$ D0 $\%$ B2 $\%$ D0 $\%$ BE $\%$ D1 $\% 8 \mathrm{E}$. pdf. 
8. Про публічну службу : Закон Естонії від 25.01.1995 р. Публічна служба. Зарубіжний досвід та пропозииї для України / за заг. ред. В.П. Тимощука, А.М. Школика. Київ : Конус-Ю, 2007. 735 с. C. 467-520.

9. Про публічну службу : Закон Литви від 23.04 .2002 р. С. $427-454$.

10. Про державну цивільну службу : Закон Латвії від 07.09.2000 р. С. 455-466.

11. Про цивільну службу : Закон Польщі від 18.12.1998 p. С. $388-426$;

12. Про державного службовця : Закон Болгарії від 27.08.1999 p. С. 601-638.

13. Стаття 12 Статуту Ради Європи від 05.09.1949 p.

14. Тестові завдання 3 англійської i французької мови. URL: https://nads.gov.ua/vyshhyj-korpusderzhavnoyi-sluzhby/testuvannia/testuvannia-navolodinnia-inozemnoiu-mo/.

15. Критерії оцінювання володіння іноземною мовою. URL: http://nads.gov.ua/page/protokol-no-10zasidannyakvkds-vid-12-chervnya-2018-roku.

16. Про структуру апарату Верховної Ради України : Постанова ВРУ від 20.04.2000 р. Дата оновлення: 11.07.2006 p. URL: https://zakon.rada.gov.ua/laws/ show/1678-14.

17. Про затвердження Положення про Апарат Верховної Ради України : Розпорядження Голови ВРУ від 25.08.2011 р. Дата оновлення: 21.06.2018 р. .

18. Питання забезпечення діяльності Президента України: Указ Президента України від 20.06.2019 р. дата оновлення: 20.06.2019 p. URL: https://zakon.rada.gov.ua/laws/show/417/2019 .

19. Про Положення про Офіс Президента України : Указ Президента України від 25.06.2019 р. Дата оновлення:10.09.2019p.URL:https://www.president.gov.ua/ documents/4362019-27681 .

20. Про Кабінет Міністрів України: Закон України від 27.02.2014 р. Дата оновлення: 27.12.2019 р. URL: https://zakon.rada.gov.ua/laws/show/794-1.

21. Про затвердження Положення про Секретаріат Кабінету Міністрів України : Постанова КМУ від 12.08.2009 р. Дата оновлення: 30.01 .2020 р. URL: https://zakon.rada.gov.ua/laws/show/850-2009-\% $\mathrm{D} 0 \% \mathrm{BF}$.

22. Про Раду національної безпеки і оборони України : Закон України від 05.03.1998 р. Дата оновлення: 11.01.2019 p. URL: https://zakon.rada.gov.ua/laws/ show $/ 183 / 98-\%$ D0 $\%$ B2 $\%$ D1 $\% 80$

23. Питання Апарату Ради національної безпеки і оборони України: Указ Президента України від 14.10.2005 р. Дата оновлення: 25.10 .2017 p. URL: https://zakon.rada.gov.ua/laws/show/1446/2005.

24. Про Конституційний Суд України : Закон України від 13.07.2017 р. Дата оновлення: 05.08.2018 р. URL: https://zakon.rada.gov.ua/laws/show/2136-19.

25. Про судоустрій і статус суддів : Закон України від 02.06.2016 р. Дата оновлення: 01.01.2020 p. URL: https://zakon.rada.gov.ua/laws/show/1402-19.

26. Про Центральну виборчу комісію : Закон України від 30.06.2004 р. Дата оновлення: 01.01.2020 р. URL: https://zakon.rada.gov.ua/laws/show/1932-15.

27. Про Положення про Секретаріат Центральної виборчої комісії: ПостановаЦВК від 19.06.2015 р. Дата оновлення: 30.01.2020 p. URL: https://zakon.rada.gov.ua/ laws/show/v0092359-15.

28. Про Уповноваженого Верховної Ради України 3 прав людини: Закон України від 23.12.1997 р. Дата оновлення 28.11.2019 p. URL: https://zakon.rada.gov.ua/ laws/show/776/97-\% D0\% B2\% D1\% 80.
29. Про затвердження Положення про Секретаріат Уповноваженого Верховної Ради України з прав людини: Наказ Уповноваженого ВРУ з прав людини від 20.06.2012 р. Дата оновлення 20.06.2012 p.

30. Про Рахункову палату: Закон України від 02.07.2015 p. Дата оновлення 04.021.2019 p. URL: https://zakon.rada.gov.ua/laws/show/576-19.

31. Про затвердження Типових вимог до осіб, які претендують на зайняття посад державної служби категорії «А»: Постанова КМУ від 22.07.2016 p. Дата оновлення: 19.10 .2018 р. .

32. Про статус чиновників : Федеральний Закон ФРН від 31.03.1999 р. Публічна служба. Зарубіжний досвід та пропозииї̈ для України / за заг. ред. В.П. Тимощука, А.М. Школика. Київ : Конус-Ю, 2007. 735 c. C. $225-269$.

33. Про службу державних службовців у адміністративних установах і про винагороду публічних службовців та інших працівників адміністративних установ : Закон Чеської Республіки від 26.04.2002 р. C. 269-388.

\section{Анотація}

Панова Н. С. Вимоги до осіб, які претендують на вступ на державну службу. - Стаття.

У статті проаналізовано вимоги до осіб, які претендують на вступ на державну службу, щодо їх можливості застосовувати у межах визначених за посадою повноважень спеціальні знання, уміння (здатність належно виконувати певні дії, заснована на доцільному використанні особою набутих знань і навичок) та навички (тобто дії, складові частини яких у процесі формування стають автоматичними), виявляти відповідні моральні та ділові якості для належного виконання встановлених завдань і обов'язків, навчання, професійного та особистісного розвитку.

Вимоги до осіб, які претендують на вступ на державну службу класифіковано залежно від категорії посади державної служби, на яку особа вступає, від юрисдикції державного органу, від нормативно-правових засад діяльності відповідного державного органу, від завдань та змісту роботи, яку зобов'язаний буде виконувати державний службовець. Досліджено зміст загальних вимог, які висуваються до осіб, що претендують на посади державної служби категорії «А»: загальний стаж не менше 7 років, досвід роботи, вільне володіння державною мовою, володіння іноземною мовою, яка є однією з офіційних мов Ради Свропи. Визначено, що досвід служби в органах місцевого самоврядування є професійною діяльністю на постійній основі осіб, які займають виборні посади, на які вони обираються на місцевих виборах; виборні посади, на які вони обираються або затверджуються відповідною радою; посади, на які вони призначаються сільським, селищним, міським головою, головою районної, районної у місті, обласної ради на конкурсній основі чи за іншою процедурою, передбаченою законодавством України.

Звернуто увагу на особливості зарубіжного досвіду щодо особливостей вимог про освіту до осіб, які претендують на посади публічної служби, а також взаємозалежність між рівнем освіти і службовим званням державного службовця. Визначено необхідність подальшого удосконалення системи вимог шляхом виокремлення вимог щодо особистісних якостей кандидатів на посади державної служби.

Ключові слова: вступ на державну службу, професійна компетентність, професійні вимоги, загальні вимоги, спеціальні вимоги, кандидати на посаду державної служби, уміння та навички. 


\section{Summary}

Panova $N$. S. Requirements for candidates for employment in the civil service. - Article.

The article analyzes the requirements for candidates for employment in the civil service in terms of their ability to apply specific knowledge, competence within the post's authority (ability to perform certain actions adequately based on the expedient use of a person's knowledge and expertise) and skills (i.e. actions the components of which become automatic in the process of shaping), to identify the appropriate moral and business qualities for the proper fulfillment of the tasks and responsibilities, training, professional and personal development.

The requirements for candidates for employment in the civil service are classified according to the category of civil service post to which the person gets into, the jurisdiction of the state agency, the legal framework of the activity of the respective state agency, the tasks and content of the work which will be performed by a civil servant. The paper studies the content of the general requirements for candidates for civil service post of the category " $\mathrm{A}$ " total experience is at least 7 years, hands-on experience, fluency in the official language, command of a foreign language, which is one of the official languages of the Council of Europe. It is determined that the experience of career in local self-government bodies is a professional activity on a permanent basis of persons holding elective positions to which they are elected at local elections; the elective offices to which they are elected or approved by the relevant council; posts to which they are appointed by the village, settlement, city mayor, mayor of district, district in the city, regional council by means of competition or other procedure stipulated by the legislation of Ukraine.

The author draws attention to the peculiarities of foreign experience regarding the peculiarities of education requirements for candidates for public service posts, as well as the interdependence between the level of education and the rank of a civil servant. The author defines the necessity of further improvement of the system of requirements through identifying the requirements for the personal qualities of candidates for public service posts.

Key words: civil service entrance, professional competence, professional requirements, general requirements, special requirements, candidates for civil service post, skills and expertise. 